\title{
INTRODUCTION
}

\section{Scope and method}

Burmese: An Introduction to the Script (referred to henceforth as BIS) aims to enable students with no previous knowledge of Burmese to become competent in reading and writing Burmese script.

Traditionally, script courses have relied on a romanization as a way of indicating to the learner the sound associated with a given Burmese letter: "the letter $\curvearrowright$ represents the sound $b, "$ and so on. This approach works up to a point, but romanizations have serious disadvantages. Learners often confuse the sounds the roman letters are meant to stand for: pain sometimes gets read as $\stackrel{0}{\hat{C}}$ (like English pine) and sometimes as $\circlearrowright \oint$ (like English pane). And romanizations suggest mistaken pronunciations: lay makes people rhyme 600 with English lay, and Min makes them rhyme $\omega \hat{c}$ : with pin. (On ways of representing Burmese in roman letters, see below: Burmese in roman letters.)

Now that cassette tape players are within reach of most students, using tape recordings seems the obvious escape route from the romanization problem. BIS presents the sounds associated with the characters of the Burmese script as sounds, on tape, and not as roman letters on the page. (The romanization is used, but sparingly, to aid the memory when characters are first presented.) The aim is to cut out the intermediate step of romanization and its pitfalls, and thereby to enable the learner to establish a more immediate and accurate link between sound and symbol.

It is assumed that students who are working through BIS will at the same time be learning to speak Burmese, and that their spoken language lessons will include some guidance and practice in pronunciation. For this reason, BIS does not give exercises in pronunciation. However, some coverage of pronunciation is unavoidable: you can't learn what sound a letter represents unless you can recognize the sound. So BIS includes some observations on sounds, and even here and there an opportunity to practise sounds, but this element is kept to a minimum. Where there is an overlap between what BIS says about pronunciation and what you are told on the subject in your spoken language course, you will often find that a little repetition is not unwelcome, and may even be helpful.

\section{Lesson structure}

The typical Lesson begins by presenting one or two new characters - in the text you see their shapes and how to draw them, and on the tape you hear the sounds they represent. Then there is a Practice section: a list of words that are both printed on the page and read out on the tape. Learners can use the words either (a) as reading practice, by pausing the tape, reading a word aloud, and listening to the tape again for confirmation; or (b) as writing practice, by listening to the word first, then pausing the tape and writing down the word, and checking with the printed list for confirmation. You can use the whole list for reading and then again for writing; or use part of it one way and part of it the other.

In the first three Lessons there are two separate lists of words: one set for reading and one for writing. 
Letter names. Most of the letters in the Burmese alphabet have a descriptive name. In reading classes in English primary schools, teachers sometimes tell children that "Cap" is spelled with "curly k-," but "Keep" is spelled with "kicking k-." Burmese letter names are similar: "twisty S," "capped $\mathrm{P}$, " and so on.

While you are learning to read Burmese script it is often useful to be able to refer to the letters by name, so the names are introduced in each Lesson. At this stage it is only necessary for learners to be able to recognize a name when they hear it, so there are no Exercises to help learn the names.

Later on, when you can speak Burmese a little, it is handy to be able to ask how something is spelled - there are a number of sounds in Burmese that can be spelled one way or another - and to be able to follow the answer. I hope to write a supplement to BIS designed to help you acquire this skill.

Review. For those who simply want to review the ground they have covered, or who are coming back to Burmese after a break and need to brush up their reading, BIS provides Review Exercises. The Review Exercises are recorded on a separate tape, and are not accompanied by explanations. The text to be used with this tape is printed at the appropriate point in this booklet: the Review of material presented and practised up to Lesson 12 is printed following Lesson 12, and so on.

\section{Take heart}

Learning a new script imposes a heavy load on your memory, not at the very beginning, but after a few Lessons, when your mind begins to bulge under the strain. You feel your recognition of the writhing mass of symbols and sounds is rapidly diminishing, and each new arrival weakens your hold on the old. Don't despair: persevere. There comes a phase after that, when you wonder why you thought it was difficult. And remember that the Burmese alphabet only has 33 consonants and some eight vowels (and no capitals), as against the 26 lower case and 26 capitals of the roman alphabet.

\section{To the teacher}

$B I S$ is written in such a way that Learners can work through it on their own, without a Teacher. However, a Teacher can help in two ways. First he or she can present the material of the next Lesson in class, so that when the Learners come to study it in their own time it will already be partly familiar. Secondly, after the Learners have worked through a Lesson on their own, the Teacher can practise the material in class. Here are some activities you may find helpful.

1. The teacher gives the number of an example in the text, the Learners find the example on the page and one (or more) of them reads it aloud.

2. The Teacher (or a Learner) reads a word aloud, and the other Learners find where it is on the page.

3. The Teacher (or a Learner) writes a word on the blackboard, and one of the Learners (or more) reads it aloud.

4. The Teacher (or a Learner) says a word, and the other Learners write it down. Their work is then checked by the Teacher (or another Learner). 
If you wish to give some extra homework tasks to provide variety, you can try the following:

1. The Teacher issues a passage from a book, and the Learners mark on it any words or syllables they recognize.

2. All the examples in Part I of Burmese: An Introduction to the Spoken Language are written in both script and romanization. The Teacher can specify a set of lines in that volume, and the Learners' task is to identify which words are not pronounced as written.

3. The Teacher issues a list of words written as pronounced, and the Learners' task is to write out the correct spelling - looking it up if they need to. This activity cannot start till after the first mismatch words have been introduced in Lesson 13.1 or later.

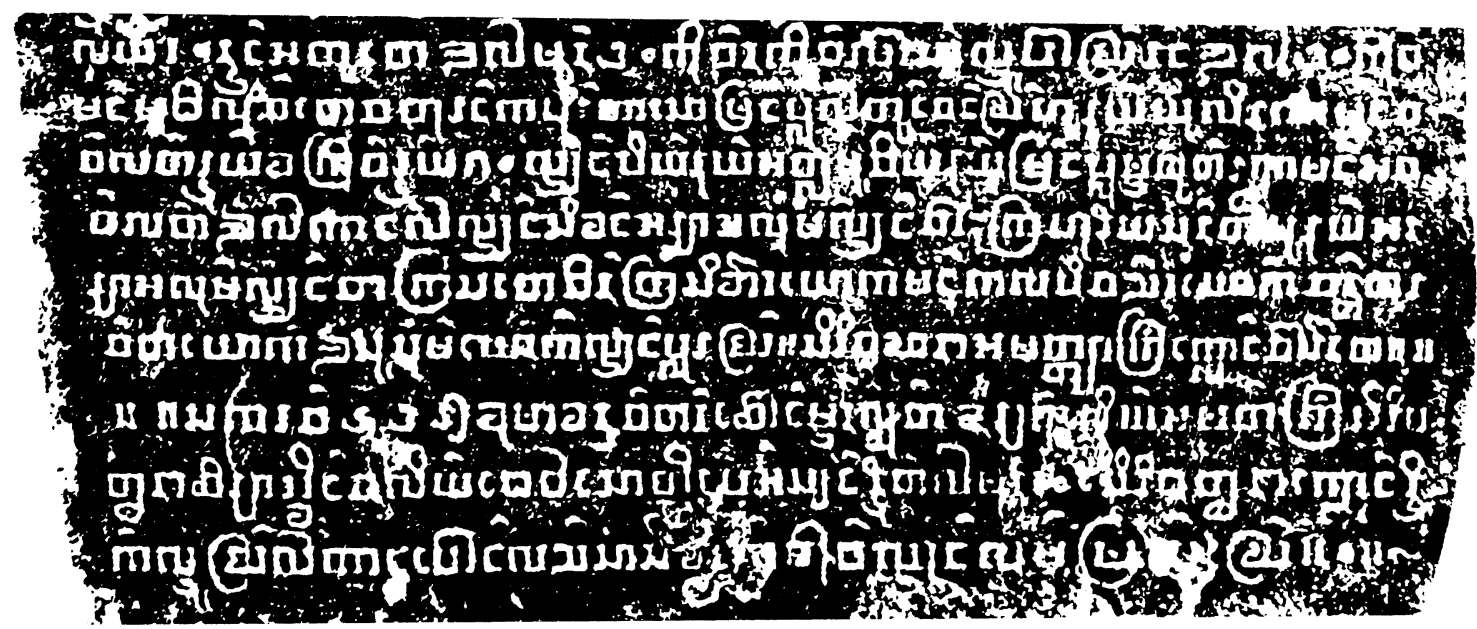

Taken from an inked "rubbing" (List $n \div 349$ ), in which the letters incised in the stone appear white against a black background

\section{HISTORY}

The earliest examples of writing in Burmese are found on stone inscriptions dating from the 11th and 12th centuries. The letters of the inscriptions are square, as opposed to the rounded shapes of the present day, and some of the spellings have changed over time, but otherwise the writing system has changed little. The script was probably acquired from the Mon people, who inhabited the Moulmein-Pegu area at the time, and the Mon in turn seem to have adopted a script used in the area of Madras on the east coast of India. (For more detail see Roop's Introduction to the Burmese Writing System, p. ix f.)

The purpose of most of the inscriptions is to make a permanent record of the dedication of land, buildings and other property to the religion. Other texts produced before the advent of printing in the 19th century were written either on paper or palm-leaf. 
The paper was like a thick lightweight card about 18 inches wide. It was made in lengths

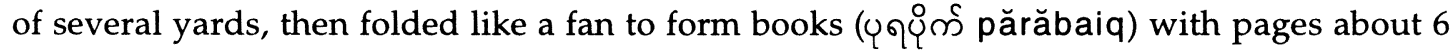
inches long. In one type of parabaik the paper was coloured black, and you wrote on it with a white steatite rod like a slate pencil. In the other, the paper was white, and written on in ink. For further information on this subject, see The Life of the Buddha, by P. Herbert (London, The British Library, 1993).

Lines from a palm-leaf manuscript copied in 1871

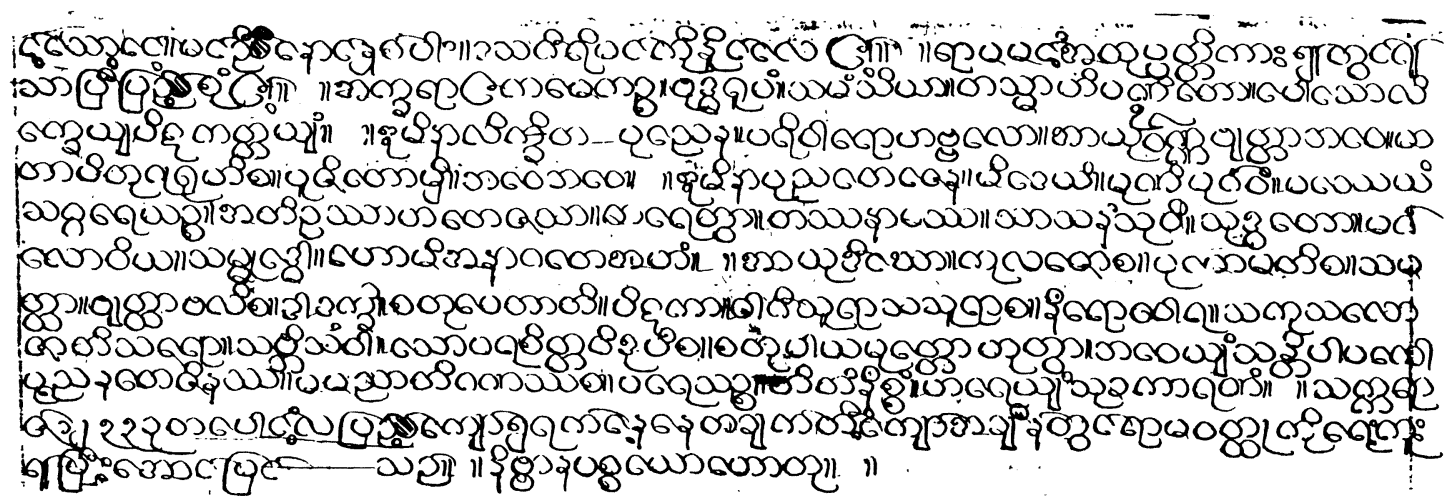

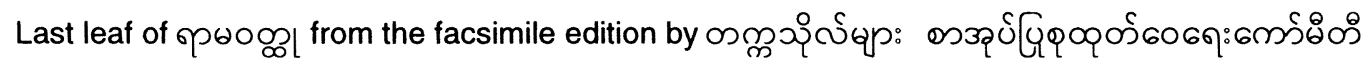

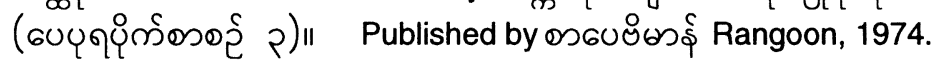

Palm-leaf is a longer lasting material. The leaves were selected and prepared, then cut into even strips about 18 inches long and 4 inches wide, and stacked up and provided with covers to form a book (600 pe-za). The letters were incised in the surface of the leaf with a sharp metal stylus, then rubbed with black to make them more legible.

The main texts for which the Mon-Burmese script was first used were not in Mon or in Burmese, but in Pali. Pali is a dead language of ancient India, related to Sanskrit and the other Indo-European languages, and is the language in which the scriptures of Theravada Buddhism, the branch of Buddhism practised in Burma, are written. As the language of the sacred texts Pali is held in high esteem in Burma. The texts and their language have been studied by the Burmese for over nine centuries, and Pali is used a a source for loanwords in the same way that Greek and Latin are used for new words in English.

As the Mon-Burmese script was developed for Indian languages, of which Pali is one, it was ideally suited for writing Pali (which can also be written satisfactorily in Thai, Cambodian, Lao, Sinhalese and other scripts - all descended from the same source as the Burmese script), but less suitable as a vehicle for Burmese and Mon. Predictably, there are sounds in Pali that don't exist in Mon and Burmese, and vice versa. This has had two results. One is that the early Mon and Burmese scholars had to devise modifications of the characters to represent the Mon and Burmese sounds that were missing (just as European languages have had to devise combinations like $c h$ and $s h$, and characters like $\ddot{u}, c ̧, ø$, and so on). The other is that the Mon-Burmese alphabet still contains a residue of letters that are not needed for writing Mon or Burmese words. However, this doesn't mean that they 
are never used in Burmese texts. When Burmese borrows a word from Pali, it still spells the word in the way it is spelled in the Pali texts, including the characters that are not used for writing Burmese words (just as we write fiançé in English although we don't use ç and é for writing English words). Many of the words that use these non-Burmese characters belong to learned vocabulary (religion, grammar, medicine), but some of them are current in everyday

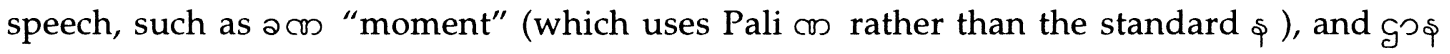
"department" (which uses Pali $g$ rather than the standard $\infty$ ).

\section{Burmese pronunciation of Pali words}

The pronunciation of Pali words in Burmese differs in two ways from their pronunciation in India, Sri Lanka and elsewhere. Firstly, there are the sounds that are needed for Pali but not used in Burmese (like German ch, which is not used for native English words). These are given the Burmese sound nearest to them (like the English pronunciation of German Bach as "bark"); for example, the voiced aspirate Pali sound written 20 in Burmese script and gh in romanized Pali: in Burmese this character is given the same sound as the unaspirated $\cap$, romanized $g$. Secondly, there have been changes in Burmese pronunciation since the script was established, and these changes are also applied to words from Pali; for example, the Pali word o ${ }^{\Theta}=$ pañcama "fifth" is pronounced /pyin-zămá/, because the earlier /c/ has changed to $/ \mathrm{s} /$ and has then been voiced to $/ \mathrm{z} /$. As a result it is not always easy for foreign and Burmese scholars of Pali to communicate orally. Where the foreigner says: Buddham saraṇam gacchāmi, the Burmese says: Bouq-dan thărănan giq-sha-mí. There is a similar mismatch in the pronunciation of Latin by, say, a Spaniard and a German.

$B I S$ has a section towards the end for learning to read words with Pali characters, though one or two characters are introduced earlier because they are used in common words.

\section{BURMESE IN ROMAN LETTERS}

Because Burmese has its own script, people writing about Burma in roman-script languages (like English) have been obliged to devise ways of representing Burmese names and words in the roman alphabet. People who are more interested in the spelling of the words than in their sound (such as historical linguists, epigraphists) have established a set of correspondences between Burmese letters and roman letters, so they can represent Burmese words in roman by consulting a table of equivalents and simply substituting roman letters for Burmese letters. We call this letter-for-letter method a "transliteration." There is an example of a transliteration table at the end of this book.

The transliteration tables are constructed to match similar tables for classical languages of India, like Pali and Sanskrit, and because the pronunciation of Burmese has changed over time, the roman letters used for transliterating are not a very helpful guide to the way the words are pronounced today; so, for people who are more interested in the sound of Burmese words than in their spelling, transliteration is not an appropriate method of romanization.

To represent the sounds of Burmese words in roman letters, rather than their spelling, many different systems have evolved. There are two main approaches. In the earliest days of 
contact between Burma and Europe, European travellers would write the best approximation they could manage to the sound of a Burmese word or name. Although a few of the details of the method have changed (for example, people now write Wun for the 18/19th century Woon), this approach is still widely used today by people writing about Burma in English and other European languages. For this reason we call this the "traditional romanization."

One advantage of the traditional romanization is that, thanks to its widespread use, it is familiar to many readers, both Burmese and foreign. For some purposes, however, it has serious shortcomings. As I have written elsewhere,

For a language learner ... the traditional romanization is far from adequate. Words romanized in the ad hoc traditional way don't show tone, they don't reliably show whether a consonant is aspirated or not, and they don't always distinguish one vowel from another. As a result, the syllable written "pe" (for example) in the traditional romanization, may represent any one of 12 different syllables in pronunciation:

$\begin{array}{llllll}60 & 60 & 60: & 00 \tilde{5} & \grave{0} & \text { ò } \\ 60 & 60 & 60: & 00 \tilde{5} & \vdots & 0\end{array}$

For the learner of the language, ambiguity of this order is intolerable. It is like providing, for a learner of English, one written syllable to cover the sounds of the eight English words pat, bat, pet, bet, pad, bad, ped, and bed.

A further deficiency is that traditional romanization often offers two, or sometimes three, different ways of romanizing the same sound. So the Burmese word 66, for example, may be romanized me, or may, or mae. This inconsistency is particularly rife in Burmese personal names, where some people deliberately adopt a variant spelling for their own name in order to make it more distinctive.

From: Burmese: An Introduction to the Spoken Language, parallel with this volume

For these reasons, linguists and others have devoted much ingenuity to devising systems of romanization where each Burmese sound is consistently and unambiguously represented by one roman equivalent - whether that is one letter or a sequence of letters. We call romanizations of ths type "systematic romanizations."

Unfortunately the problem of matching Burmese sounds and roman letters is so great that hardly any two linguists find the same system satisfactory. As a result, there are many variations on the same theme. Each system is entirely consistent and systematic within itself; but one will use the roman letter $e$ (for example) for one Burmese vowel sound, and another system will use it for a different vowel sound.

Following this tradition with some reluctance, I have perpetrated yet another systematic romanization system to use in this course and its sister language books. I have done this because I believe the new variations are easier for students to use than the alternatives. However, the best solution to the romanization problem is the most radical:

Don't use a romanization: learn the script instead. 


\section{SELECTING VOCABULARY FOR SCRIPT PRACTICE}

\section{Linking script learning with learning the spoken language}

How can you start to learn a language with a non-roman script? You have to be able to handle the script before you can read or write down any words to learn; but it's not easy to learn the script unless you can recognize the words you are reading: mouthing meaningless syllables is a demoralizing endeavour.

The obvious candidates for script practice are the first words you learn to speak: each new word you learn to say, you also learn to read and write in the script, so all the words you read and write are words you already know. With this advantage in mind, I intended originally to design $B I S$ as a parallel course to the early parts of my spoken language course (Burmese: An Introduction to the Spoken Language, abbreviated to BISL).

When you get down to the details, however, you find that the assumed advantages of this plan are less enticing than they seem. The vocabulary you need in the early stages of a spoken language course contains a high proportion of words with spelling irregularities of one kind or another (see Irregular spellings below), and such words are not at all suitable as material for a well-graduated introduction to the (mostly) systematic way in which the letters of the Burmese script represent the sounds of the spoken language.

For this reason I abandoned the attempt to link the vocabulary used for practice in BIS with the vocabulary presented in the early stages of BISL, and decided to write BIS as an independent entity. This loses the rewards of running parallel with the acquisition of the spoken language, but it has some compensating advantages. You can still use the script course at the same time as you are working through a spoken language course - mine or any other. In addition, BIS can be taken at whatever pace suits the timetabling arrangements of the students, and they can start doing it when they like. They can start the script course before they start the spoken course, or defer starting it till after they are well into the spoken course; and they can either take it intensively, or space it out, to match the time they have to spend on it.

\section{Irregular spellings in everyday vocabulary}

The Burmese writing system has been in use in its present form for several centuries. During this time the pronunciation of a number of words has changed, but the spelling has not changed to match. As a result there are many words that look, from the written form, as if they should be pronounced one way, though in practice they are pronounced another way. Here are some examples: 


\begin{tabular}{|c|c|c|c|c|c|}
\hline written form & $\begin{array}{l}\text { pronuncia } \\
\text { spelled * }\end{array}$ & $\begin{array}{l}7 \text { script } \\
\text { as spoken }\end{array}$ & $\begin{array}{l}\text { pronunciation } \\
\text { spelled }\end{array}$ & 7 roman & meaning \\
\hline эрศР: & $\begin{array}{l}\text { as spellec } \\
\text { / y } 10 \text { : }\end{array}$ & $\begin{array}{l}\text { as spoken } \\
\text { /ows:/ }\end{array}$ & $\begin{array}{l}\text { as spelled } \\
\text { bú-yà }\end{array}$ & $\begin{array}{l}\text { as spoken } \\
\text { p'ăyà }\end{array}$ & pagoda \\
\hline 6ேஸீก் & 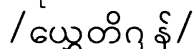 & / 60్రుЗnई/ & shwe-tí-goun & shwe-dăgoun & Shwedagon \\
\hline จร์ & /วฐ์// & 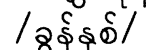 & k'ú-hniq & k'un-hniq & seven \\
\hline ప్యు & / యును/ & 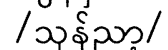 & thú-nyá & thoun-nyá & zero \\
\hline \$ృఠనీ & / इวघे| & / \$ईชư/ / & na-myi & nan-meh & name \\
\hline
\end{tabular}

A more systematic divergence between script and sound is due to "weakening," a feature that is predictable in some words (such as number phrases with one, two, seven) but not in all; for example:

\begin{tabular}{|c|c|c|c|c|c|}
\hline ంळீంుీ & 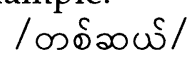 & / கనంuు / & tiq-s'eh & tăs'eh & ten \\
\hline & / క̧ీలు / & / sous/ & hniq-ya & hnăya & two hundred \\
\hline Sీ & 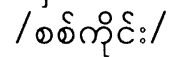 & / ๔గ̊c: c./ & Siq-kaìn & Zăgaìn & Sagaing [town] \\
\hline & lonil & / oñ/ & Pú-gan & Păgan & Pagan [town] \\
\hline$\varepsilon_{-\varepsilon}$ & / טई:mई / & / แัก/ & pàn-kan & păgan & plate, bowl \\
\hline
\end{tabular}

But the most pervasive problem for the beginner is "voicing," a feature that is often predictable (e.g in suffixes like - $\infty \mathfrak{\omega}$ or $-\infty$ ), but not always; for example:

\begin{tabular}{|c|c|c|c|c|c|}
\hline $\begin{array}{l}\text { ñ } \\
\vdots \\
\text { कuీ }\end{array}$ & 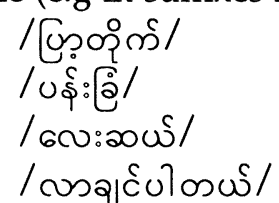 & 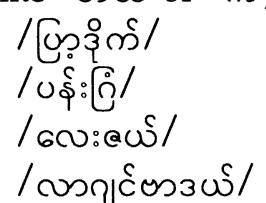 & $\begin{array}{l}\text { iq } \\
\text { an }\end{array}$ & $\begin{array}{l}\text { pyá-daiq } \\
\text { pàn-jan } \\
\text { lè-zeh } \\
\text { la-jin-ba-deh }\end{array}$ & I want to \\
\hline
\end{tabular}

Another set of words that present problems for the beginner student of the script are those with non-standard spellings - spellings that use rare characters or rare combinations of characters; for example:

\begin{tabular}{|c|c|c|c|c|}
\hline $\begin{array}{l}\text { non-standard } \\
\text { element }\end{array}$ & orthography & $\begin{array}{l}\text { pronounced } \\
\text { as if spelled }\end{array}$ & $\begin{array}{l}\text { pronunciation } \\
\text { in roman }\end{array}$ & meaning \\
\hline$-\infty$ & অm্লা & वर्ताn & seq-ku & paper \\
\hline - & 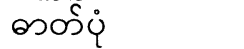 & उஸ์ & daq-poun & photograph \\
\hline$\underline{\varepsilon}$ & ชก์กันง & बर́niasoss & Min-găla-ba & Good morning \\
\hline - ई & बఏ 600: & Qิई:360: & Màn-dălè & Mandalay \\
\hline - & 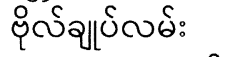 & 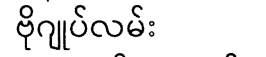 & Bo-jouq Làn & Bogyoke Street \\
\hline-2 & aus, & 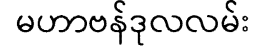 & Măha Ban-dú-lá Làn & Maha Bandoola St \\
\hline
\end{tabular}

Learning a new script demands a sustained and committed effort from the learners. When they have just struggled through to the stage of being able to read c'in and pa and teh, to have their teacher tell them at that point that "in some contexts these words are actually pronounced jin and ba and deh" is demoralizing and counterproductive. The same is true of having to tell students who are justifiably proud of having learned to read 3 ऽ (daq) that in the word for "photograph" (daq-poun) you have to write

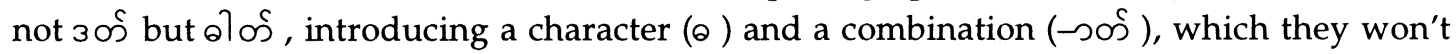
need for any other words for a long time to come. It is for these reasons that vocabulary from the early lessons of BISL is not used for script practice in the early parts of BIS. 


\section{Words suitable for script practice}

Given that so many words in the normal everyday vocabulary are unsuitable as material for learning to read the script, words for practice have to be found elsewhere. To be suitable for this purpose, words have to meet two requirements: (a) they must be free from the voicing, weakening, non-standard letters, and miscellaneous irregularities exemplified above; and (b) they should be words that the learner can recognize, even though he may not yet know many words of Burmese.

There are two categories of words that meet these requirements. One is Burmese personal names, which almost always consist of discrete syllables without irregularities or rare letters. An added advantage of using personal names for practice is that learners will become more familiar with the elements and shapes of names. Names play a larger part in Burmese discourse than they do in the West (for example, Burmese often uses names where English uses "you" and "I"), and they are not marked in the script with capital initial letters, so the ability to handle and recognize names is an important skill for the foreign learner.

The second category of words that meet the requirements is foreign words that are used in

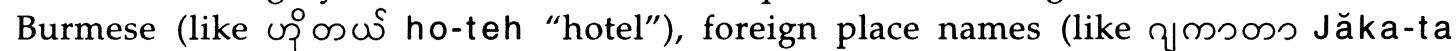
"Jakarta"), and the foreign first names that some Burmese use as nicknames (like 6ชร์กำ Maw-li "Molly"). All these are written in Burmese script in a way that exactly reflects the way they are pronounced when spoken with a strong Burmese accent. A possible objection to using this category for practice is that the learners are not learning Burmese words. However, loanwords and foreign names do offer a high degree of regularity and recognizability, and they have one added advantage. Many students report that, after studying and using Burmese for a year or two, failing to recognize English and other loanwords in Burmese frequently causes them difficulty. Using loanwords for script practice, as BIS does, should give you sufficient familiarity with the sound correspondences to reduce the size of this problem.

It sometimes happens, particularly in the early portion of BIS, that there are not enough names or loanwords to provide sufficient practice with a given sequence of letters. In this situation BIS uses Burmese words that the beginner is unlikely to meet elsewhere (such as os ta "embankment"), or even made-up words that don't exist in the language. As the learner progresses through the course and his/her repertoire of syllables grows, the need for words in this category eventually disappears.

Once the learner has mastered a number of common consonants and vowels, the course begins to introduce phrases with voicing and weakening and other unexpected pronunciations; so that the need for foreign or made-up words diminishes progressively and phrases from the spoken language take their place. 


\section{DETAILED CONTENTS (For use as a finder list)}

\section{Part 1: Standard characters and combinations of characters}

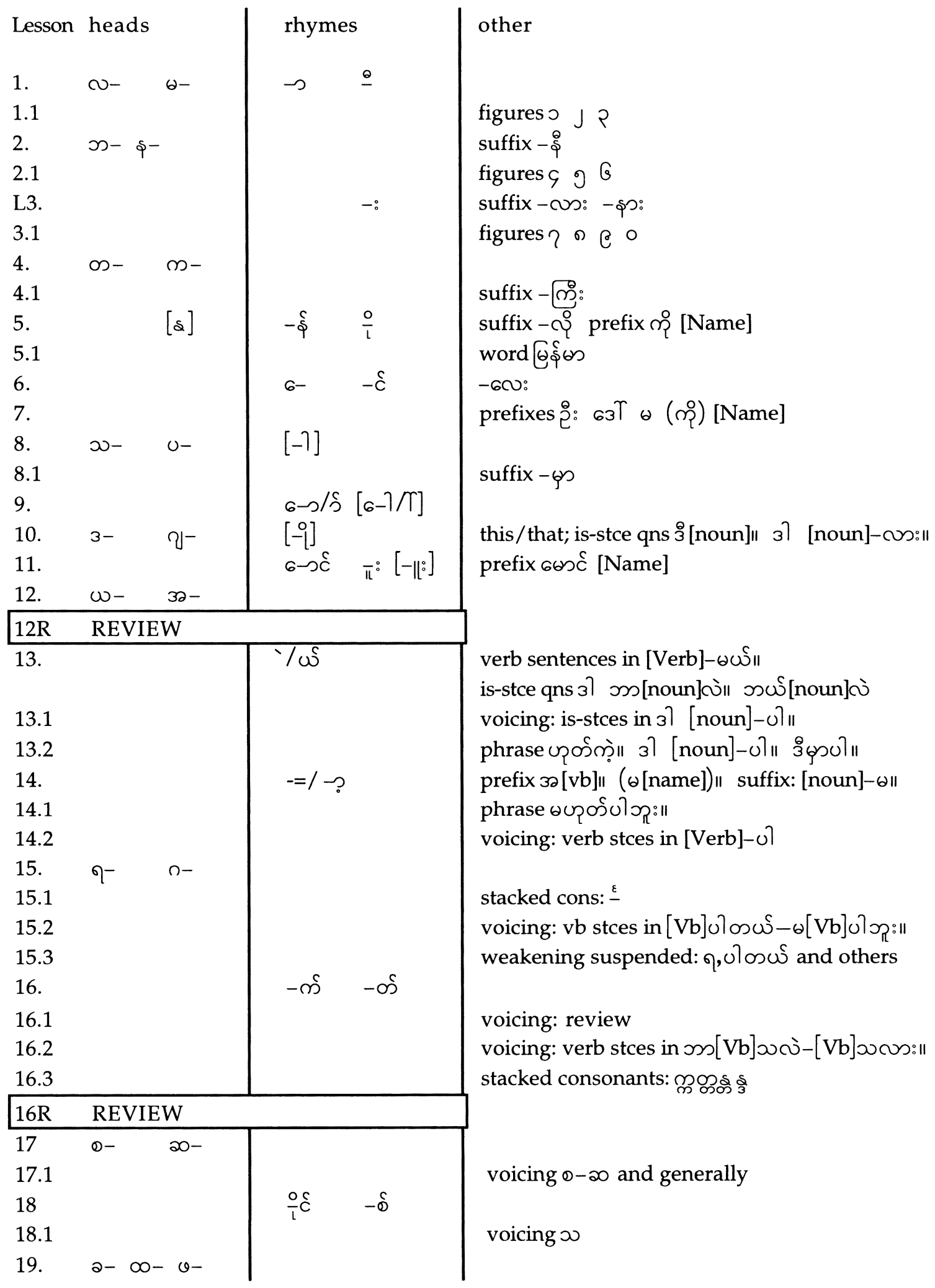




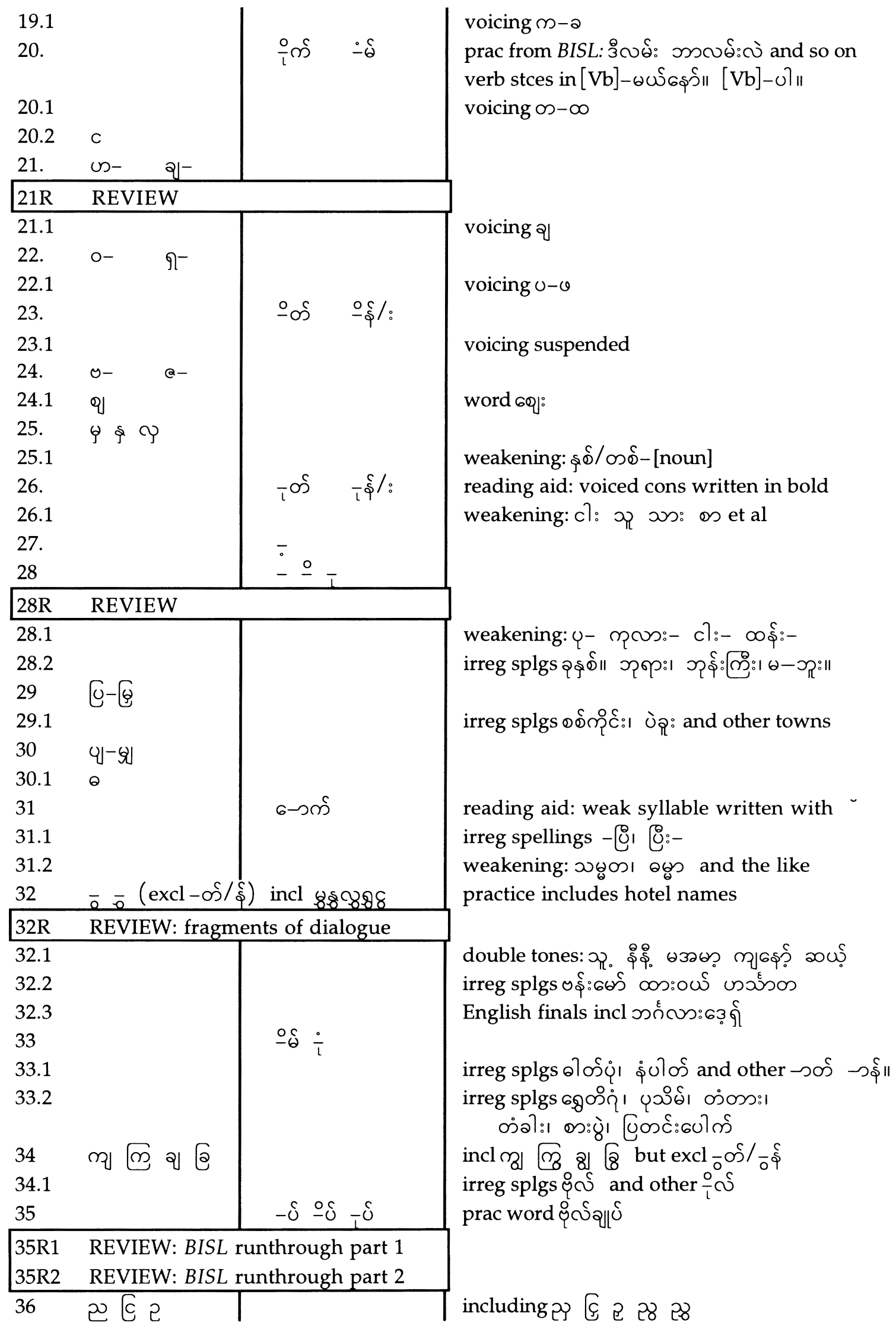


37

38

39

$-\mathrm{pt} 1$

$-\mathrm{pt} 2$

$-\mathrm{pt} 3$

$-\mathrm{pt} 4$

39.1

39.2

40

40R REVIEW: sentences from BISL Part 1 and newspaper headlines literary-style כు బీ and $\omega$

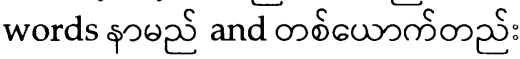

\section{Part 2: Less common characters and combinations of characters}

\section{- Rare combinations}

Section 1 기

Section 2 Y

Section 3 य్ग

Section 4 us

- Free-standing vowel syllables

Section $5 m$

Section 6 ची

Section 7

Section 8 ?

Section 9

Section 10 బ,

Section 11 ๘ర్య

- Abbreviated syllables

Section 12 का

Section 13 ด

Section 14 乌ู

Section 15 दर्ट.

- Consonants used in Pali words

Section 16 5/5

Section 17 - 2ు-

Section 18 - ్ㅣ-

Section 19 బు
Section $20 \xi$

Section 21 ल గ

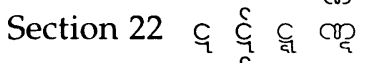

Section 23 g $\hat{g}$ c ल

Section 24 द दे ₹

Section 25 ข

- Non-standard rhymes

- Stop-class finals

Section 26 承

Section 27 * *

Section 28 6**

Section 29 両

Section 30 6*ว

Section $31 *$ *

- Nasal finals

Section 32

All vowels with non-standard nasal finals

- Other finals

Section 33

All vowels with non-standard other finals

- Symbols for Sanskrit

Section 34 Sanskrit ś-ș, r r-̣̂, !-̣ 


\section{Types of mismatch between spelling and pronunciation}

Mismatch in initial consonant

Consonant written plain or aspirate, pronounced voiced

Consonant written plain, pronounced aspirate

Consonant written voiced, pronounced aspirate

Nasal consonant written plain, pronounced aspirate

Mismatch in medial consonant

Consonant pronounced with unwritten -J

Medial consonant written but often not pronounced

Mismatch in rhyme

Vowel written 6- pronounced /ㅇ/ /

Syllables written with stacked consonant, pronounced with high tone

Unwritten final consonant

Final consonant acts as initial of next syllable

Some unique mismatches

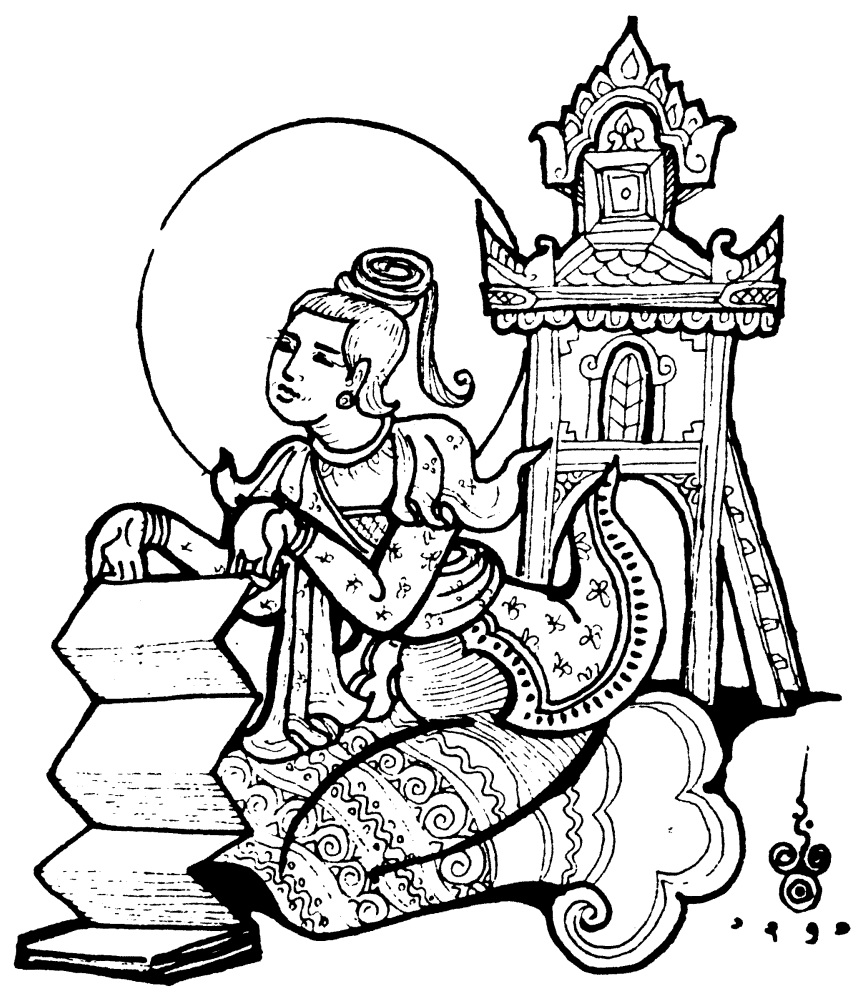

Lady in the costume of the Burmese royal court holding a parabaik, a fanfold book of stiff paper used for writing before the spread of printing. 


\section{The alphabet}

\section{Consonants}

The Burmese alphabet has 33 consonants. There are no capitals.

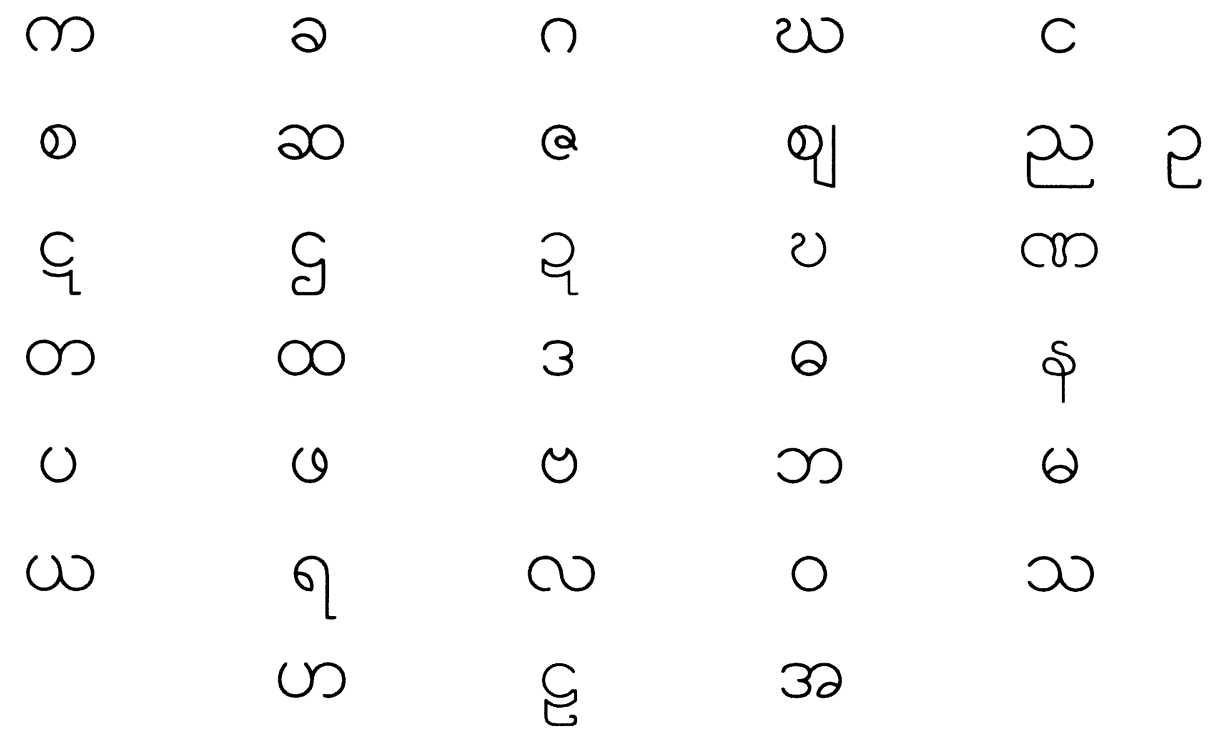

\section{Vowels}

The vowels are less systematized than the consonants. Traditionally there are 12, written in the form of free-standing syllables as follows:

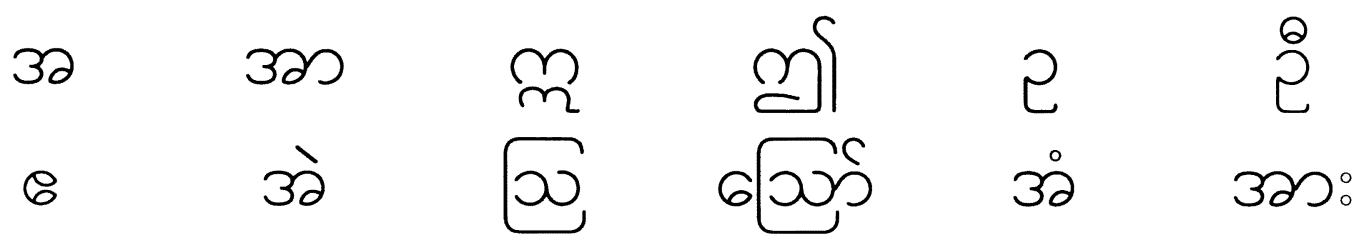

This list has several omissions and anomalies. A more complete picture is gained from listing the vowel symbols in their "attached" forms: the forms used for attaching them to consonants to make syllables. In the following list a hyphen ("--) is used to show the position of the consonant.

\begin{tabular}{|c|c|c|c|c|c|c|}
\hline low tone: & -0 & $\stackrel{0}{-}$ & $\pi$ & $6-$ & $-\omega \mathfrak{\omega}$ & $6-5$ \\
\hline high tone: & $-0^{\circ}$ & $\stackrel{0}{-}$ & $\pi^{\circ}:$ & $6-:$ & 1 & $6-0$ \\
\hline creaky tone: & - & $\underline{0}$ & $\bar{L}$ & $6-$ & $\frac{1}{0}$ & $6-?$ \\
\hline
\end{tabular}

Other rhymes are represented by adding a final consonant to these consonant+vowel combinations. For a full listing of combinations and additional symbols see Appendix 1: Conspectus. 